УДК 636.2.034

(C) 2012

Вацький В. Ф., кандидат сільськогосподарських наук, Величко С. А., аспірант *

Полтавська державна аграрна академія

\title{
ВПЛИВ ОКРЕМИХ ФАКТОРІВ НА МАСУ ТЕЛЯТ ПРИ НАРОДЖЕННІ І МОЛОЧНУ ПРОДУКТИВНІСТЬ ЇХ МАТЕРІВ
}

\section{Рецензент - кандидат сільськогосподарських наук Д. В. Ломако}

Представлені результати досліджень із вивчення впливу тривалості ембріогенезу, ембріональної швидкості росту, статі телят, материнського та батьківського впливу на масу телят при народженні, а також впливу окремих із ијих факторів (тривалості ембріогенезу, ембріональної швидкості росту, маси телят при народженні) на молочну продуктивність корів-матерів. Встановлено, що маса телят при народженні залежить від ембріональної швидкості росту і не залежить від тривалості ембріогенезу, яка, попри біологічну обумовленість, має високий ліміт мінливості. Не встановлено суттєвого зв'язку показників ембріонального розвитку і маси телят при народженні з молочною продуктивністю їх матерів.

Ключові слова: маса при народженні, ембріогенез, ембріональна швидкість росту, молочна продуктивність.

Постановка проблеми. Молоко і молочні продукти - надзвичайно цінні й незамінні продукти харчування. Проблема виробництва молока завжди $є$ надзвичайно актуальною, передусім в умовах сьогодення, коли відбувається підвищення собівартості та зниження обсягів виробництва молока. Отже, слід вести пошук шляхів підвищення молочної продуктивності корів засобами селекції. В селекції тварин важливо визначити їх майбутню господарську цінність у ранньому віці.

Першим можливим для визначення критерієм оцінки тварин на початку постембріонального розвитку є маса при народженні, визначення якої 3 досить високою точністю не потребує особливих зусиль. Отже, масу при народженні можна вважати важливим критерієм у селекції молочної худоби.

Наше дослідження включає аналіз даних по стаду української червоно-рябої молочної худоби і проведене для визначення факторів, що впливають на масу телят при народженні та молочну продуктивність їх матерів.
Аналіз основних досліджень і публікацій, у яких започатковано розв'язання проблеми. У селекційній роботі, направленій на підвищення молочної продуктивності, важливе значення має рання діагностика господарсько корисних ознак у тварин [10].

Показником повноцінності розвитку телят в ембріональний період $\epsilon$ тривалість ембріогенезу, що, в певній мірі, є показником життєздатності, інтенсивності обміну речовин, тобто найбільш загальних властивостей організму, що закладаються на ранніх етапах ембріонального розвитку $\mathrm{i}$, в залежності від їх вираженості, прогнозують майбутню продуктивність тварин. Тобто, тривалість ембріогенезу обумовлює ступінь розвитку тварин при народженні (коефіцієнт кореляції між тривалістю ембріонального розвитку і живою масою при народженні $\mathrm{r}=0,308)$ [3, 8, 9]. Проте цю думку не підтверджують дослідження інших вчених, які свідчать про відсутність зв'язку між тривалістю ембріогенезу і масою телят при народженні $(\mathrm{r}=-0,07)$ [6].

Встановлено наявність від'ємного зв'язку між тривалістю тільності й молочною продуктивністю корів $(\mathrm{r}=-0,178 \ldots-0,442)[3,7]$, але деякі дослідники 3 цим не погоджуються, доводячи відсутність такої залежності $[1,6]$.

Першим показником, що характеризує тварину і який можна визначити відразу після народження, є маса при народженні.

Маса при народженні впливає на масу тварин у майбутньому, проте існують різні дані стосовно ступеня іiі впливу $[1,6]$. Маса ремонтного молодняка в різні вікові періоди - універсальний показник інтенсивності їх вирощування, за яким можна робити висновки про розвиток молодняка і його продуктивні можливості [10].

Наукою встановлено позитивну залежність надою корів від їх живої маси $(\mathrm{r}=0,44 \ldots 0,47)$, що підтверджує важливість спрямованого вирощування телиць $[2,4,10,11]$.

\footnotetext{
* Керівник - кандидат сільськогосподарських наук В. Ф. Вацький
} 
Інтенсивне вирощування телиць сприяє зниженню віку першого плідного осіменіння, прискоренню обороту стада, і тим самим підвищенню економічної ефективності всієї галузі. Проте надмірно великі прирости маси телиць у період вирощування негативно впливають на їх подальшу молочну продуктивність [10].

Попередні дослідження науковців доводять, що маса телят при народженні є важливим критерієм у селекції молочної худоби, однак розбіжність поглядів науковців і недостатнє вивчення цього питання надає актуальності даному дослідженню.

Мета і завдання досліджень. Мета дослідження - з'ясувати вплив спадковості та факторів ембріонального розвитку на масу телят при народженні та молочну продуктивність їх матерів.

Відповідно до мети, перед нами постали завдання: встановити залежність між показниками ембріогенезу і масою телят при народженні; визначити вплив батька, матері і статі телят на показники ембріонального розвитку телят та їх масу при народженні; з'ясувати ступінь впливу показників ембріонального розвитку і маси телят при народженні на рівень молочної продуктивності їх матерів.

Матеріал і методи досліджень. Дослідження проведені на основі матеріалів первинного зоотехнічного обліку СВК „Батьківщина” Котелевського району Полтавської області за 2004-2011 роки. Було враховано тривалість ембріогенезу, ембріональну швидкість росту, масу телят при народженні, стать телят, вік і масу корів при отеленні та рівень їх молочної продуктивності.

Корів і телят зважували на протязі 24 годин після отелення. Ембріональну швидкість росту визначали за допомогою відношення маси при народженні телят до тривалості ембріогенезу. Молочну продуктивність корів оцінювали за показниками надою за 305 днів лактації (але не менше
240 днів) та середньодобового надою за лактацію 3 перерахунком на молоко 4 \% жирності. Перерахунок здійснювали шляхом визначення кількості 1 \% молока і ділення на 4. Масу при народженні, тривалість ембріогенезу, ембріональну швидкість росту та інші необхідні для аналізу дані ділили на три групи. Перша група мала високі показники $(\mathrm{M}>0,5 \sigma)$, друга - середні $(\mathrm{M} \pm 0,5 \sigma)$, третя - низькі $(\mathrm{M}<0,5 \sigma)$. На основі отриманих даних проведено їх статистичний, кореляційний, регресійний i дисперсійний аналіз.

Біометричну обробку одержаних даних проводили згідно з методикою Меркур'євої Е. К. [5] на ПЕОМ із використанням програмного забезпечення Microsoft Excel 2007.

Результати досліджень. Розглянемо вплив окремих факторів на масу телят при народженні.

Cтать. Маса телят при народженні до певної міри залежить від їх статі (див. табл.).

Середня маса при народженні 633 телят української червоно-рябої породи була 30,8 кг, для 178 бичків вона становила 32,4 кг, для 455 теличок 30,2 кг із лімітом 18-36 кг. Дослідження показали, що бички переважають теличок за живою масою при народженні в середньому на 2,2 кг, а за ембріональною швидкістю росту - на 7,34 г (Р>0,999).

Зв'язок статі телят із тривалістю ембріогенезу, масою при народженні та швидкістю росту телят в ембріональний період визначали 3 допомогою бісеріального коефіцієнта зв'язку $\left(\mathrm{r}_{\mathrm{b}}\right)$, який використовують при визначенні зв'язку між якісними і кількісними ознаками [5]. Встановлено наявність позитивного зв'язку між статтю та масою телят при народженні $\left(\mathrm{r}_{\mathrm{b}}=0,28\right)$, а також між статтю телят та їх ембріональною швидкістю росту $\left(\mathrm{r}_{\mathrm{b}}=0,30\right)$. Зв'язку статі телят із тривалістю ембріогенезу нами не встановлено $\left(\mathrm{r}_{\mathrm{b}}=0,04\right)$.

Показники ембріонального розвитку телят залежно від статі та жсивӧ маси при народженні

\begin{tabular}{|c|c|c|c|c|c|c|}
\hline \multirow{2}{*}{$\mathrm{n}$} & \multicolumn{2}{|c|}{$\begin{array}{c}\text { Жива маса при народженні, } \\
\text { кг }\end{array}$} & $\begin{array}{c}\text { Тривалість ембріонального } \\
\text { розвитку, днів }\end{array}$ & \multicolumn{2}{c|}{$\begin{array}{c}\text { Ембріональна швидкість } \\
\text { росту, кг }\end{array}$} \\
\cline { 2 - 7 } & $\mathrm{M} \pm \mathrm{m}$, кг & $\mathrm{Cv}, \%$ & $\mathrm{M} \pm \mathrm{m}$, кг & $\mathrm{Cv} \%$ & $\mathrm{M} \pm \mathrm{m}$, кг & $\mathrm{Cv} \%$ \\
\hline \multicolumn{7}{|c|}{ Бички } \\
\hline 49 & $34,57 \pm 0,10$ & 2,05 & $281,63 \pm 0,78$ & 1,93 & $0,123 \pm 0,001$ & 2,91 \\
\hline 76 & $32,57 \pm 0,06$ & 1,53 & $281,74 \pm 0,59$ & 1,82 & $0,116 \pm 0,000$ & 2,47 \\
\hline 53 & $30,02 \pm 0,22$ & 5,37 & $280,89 \pm 0,86$ & 2,23 & $0,107 \pm 0,001$ & 5,79 \\
\hline 178 & $32,36 \pm 0,15$ & 6,19 & $281,46 \pm 0,42$ & 1,97 & $0,115 \pm 0,001$ & 6,43 \\
\hline \multicolumn{7}{|c|}{ Телички } \\
\hline 92 & $32,70 \pm 0,10$ & 2,96 & $280,34 \pm 0,53$ & 1,80 & $0,117 \pm 0,000$ & 3,67 \\
\hline 235 & $30,39 \pm 0,04$ & 1,61 & $280,88 \pm 0,36$ & 1,98 & $0,108 \pm 0,000$ & 2,64 \\
\hline 128 & $28,12 \pm 0,13$ & 5,12 & $280,84 \pm 0,49$ & 1,96 & $0,100 \pm 0,000$ & 5,40 \\
\hline 455 & $30,22 \pm 0,09$ & 6,10 & $280,76 \pm 0,25$ & 1,94 & $0,108 \pm 0,000$ & 6,48 \\
\hline \hline
\end{tabular}


Ембріональний розвиток. Тривалість ембріонального розвитку телят (тільності маток) вважається біологічно обумовленою ознакою, хоча вона має високий ліміт мінливості (266-299 днів), що підтверджується дослідженнями Кірович Н. О. [3]. Тривалість ембріогенезу, за нашими даними, безпосередньо не впливає на масу телят при народженні $(\mathrm{r}=0,01 \pm 0,04, \mathrm{P}>0,999)$, але встановлений іiї від'ємний зв'язок з ембріональною швидкістю росту ( $\mathrm{r}=-0,27 \pm 0,04, \mathrm{P}>0,999$ для бичків і $\mathrm{r}=-0,33 \pm 0,04, \mathrm{P}>0,999$ для теличок), яка пов'язана 3 масою при народженні $(\mathrm{r}=0,95 \pm 0,01$, $\mathrm{P}>0,999)$. Встановлено, що збільшення тривалості тільності на один день супроводжується зменшенням ембріональної швидкості росту на 0,37 г, а підвищення ембріональної швидкості росту на 10 г- скороченням ембріонального періоду на 2 дні. При цьому підвищення ембріональної швидкості росту на 10 г приводить до збільшення живої маси при народженні на 2,6 кг, а збільшення живої маси при народженні на 1 кг відбувається завдяки збільшенню ембріональної швидкості росту на 3,5 грами. Отже, швидкість росту телят в ембріональний період доцільно вважати показником, від якого залежить маса телят при народженні.

Дисперсійний аналіз даних показує, що тривалість ембріогенезу обумовлює $6 \%$ мінливості ембріональної швидкості росту бичків і $12 \%$ теличок, а ембріональна швидкість росту обумовлює 79 \% мінливості маси при народженні як бичків, так і теличок. Тому доцільно розглядати сукупний зв'язок між тривалістю ембріогенезу, ембріональною швидкістю росту і масою при народженні телят. Нами встановлено: при постійному значенні тривалості ембріогенезу кореляція між ембріональною швидкістю росту і масою при народженні дорівнює 0,99; при постійному значенні ембріональної швидкості росту кореляція між тривалістю ембріогенезу і живою масою при народженні дорівнює 0,96; при постійному значенні живої маси при народженні кореляція між тривалістю ембріогенезу та ембріональною швидкістю росту дорівнюе $-0,96$. Загальна кореляційна залежність між трьома показниками $\mathrm{r}_{\mathrm{cB}}=0,997$.

Отримані результати суперечать результатам Н. О. Кірович [3], Л. О. Стріхи [8], Л. М. Хмельничого [9] щодо позитивного зв'язку між тривалістю ембріогенезу і масою телят при народженні, співпадаючи із результатами К. А. Найденко [6], які вказують на відсутність такого зв'язку.

Вилив батька. Телята від різних плідників, а також народжені в різні роки відрізнялися за ма- сою при народженні, але відмінності маси при народженні в нащадків від одного плідника в межах років його використання не встановлено. Це свідчить про вплив плідника на масу телят при народженні $\left(\mathrm{h}^{2}=0,10, \mathrm{P}>0,999\right)$.

Вилив матері. Оцінка впливу віку корів та порядкового номера отелення на масу телят при народженні не виявила достовірного впливу даних показників. Слабкий, але достовірний зв'язок був виявлений між номером отелення (до 4-го отелення) і масою теличок при народженні $(\mathrm{r}=0,14 \pm 0,05, \mathrm{P}>0,99)$, оскільки помічено, що маса теличок при народженні збільшується зі збільшенням віку матерів до четвертого отелення. При цьому з кожним отеленням телички збільшують масу при народженні на 0,27 кг. У подальшому вік корів не впливає на масу телят при народженні. Можливо, причинами цього є триваючий ріст молодих корів і незавершене формування їх органів відтворення.

Встановлено, що жива маса корів при отеленні залежить від їх віку. Ця залежність знаходиться на рівні $69 \%(\mathrm{r}=0,67 \pm 0,02, \mathrm{P}>0,999)$ при наближеному до прямолінійного зв'язку $(\mathrm{L}=0,16)$. Вік та жива маса корів при отеленні практично не впливають на масу телят при народженні. Кореляція віку та маси корів при отеленні з масою телят при народженні дорівнюе $0,08 \pm 0,04$ $(\mathrm{P}>0,95)$.

Не всі отелення проходять однаково. Іноді трапляються випадки ускладнених отелень, за яких тварини потребують кваліфікованої допомоги обслуговуючого персоналу. Встановлено, що $70 \%$ корів, які потребують допомоги при отеленні - це первістки. У нашому дослідженні не виявлено зв'язку між масою телят при народженні та частотою ускладнених отелень. Причиною цього, очевидно, було те, що в дослід не включалися дані про мертвонароджених телят.

Далі розглянемо вплив окремих факторів на молочну продуктивність корів.

Дослідження молочної продуктивності корівматерів у зв'язку із масою телят при народженні здійснювали 3 урахуванням номера лактації та статі телят. Результати досліджень не виявили достовірної кореляції живої маси телят при народженні, ембріональної швидкості росту телят і тривалості їх ембріогенезу з молочною продуктивністю корів-матерів. Ці дані не узгоджуються з результатами Н. О. Кірович [3] і Д. А. Некрасова [7], які виявили від'ємний зв'язок між тривалістю тільності та молочною продуктивністю корів, проте співпадають із результатами Н. С. Воскресенской [1] і К. А. Найденко [6], які 
свідчать про відсутність такої залежності.

Дослідженнями встановлено існування низької, але достовірної залежності молочної продуктивності корів від їх живої маси. Так, маса корів після отелення обумовлює 5 \% мінливості молочної продуктивності, а коефіцієнт кореляції маси 3 надоєм за 305 днів $\mathrm{r}=0,14 \pm 0,04(\mathrm{P}>0,999) \mathrm{i}$ 3 середньодобовим надоєм $\mathrm{r}=0,12 \pm 0,04(\mathrm{P}>0,99)$. Позитивну залежність маси корів із рівнем ї молочної продуктивності встановили й інші дослідники $[2,4,10,11]$, однак ця залежність була дещо вищою $(\mathrm{r}=0,44-0,47)$, аніж отримана в даному дослідженні. Отже, враховуючи результати попередніх досліджень науковців про позитивний зв'язок маси телят при народженні 3 їх масою в наступні вікові періоди, а також про позитивний зв'язок маси корів при отеленні з рівнем їх наступної молочної продуктивності, припускаємо, що існує вплив маси телят при народженні на подальший рівень їх молочної продуктивності, що й визначатиме напрям наших досліджень у майбутньому.

\section{БІБЛІОГРАФІЯ}

1. Воскресенская Н. С. Возрастная динамика экстерьерных и гематологических показателей крупного рогатого скота в святи с развитием и молочной продуктивностью: автореф. дис. ... канд. с.-г. наук : спец. 553 „Частная зоотехния”/ Н. С. Воскресенская. - Одесса, 1967. - 23 с.

2. Даниленко В. П. Науково-практичне обгрунтування методів формування високопродуктивного стада молочної худоби : автореф. дис. ... канд. с.-г. наук: спец. 06.02.01 „Розведення та селекція тварин” / В. П. Даниленко. - с. Чубинське Київської області, 2007. - 20 с.

3. Кірович Н. О. Раннє прогнозування молочної продуктивності та резистентність організму великої рогатої худоби в залежності від тривалості ембріогенезу: автореф. дис. ... канд. с.-г. наук : спец. 06.02.01-,Розведення та селекція тварин” / Н. О. Кірович. - Херсон, 1999. - 19 с.

4. Кропивка Ю. Г. Використання генетичного потенціалу голштинської породи для підвищення продуктивності тварин західного внутріпородного типу української чорно-рябої молочної породи : автореф. дис. ... канд. с.-г. наук : спец. 06.02.01 - „Розведення та селекція тварин” / Ю. Г. Кропивка. - Львів, 2004. - 20 с.

5. Меркурьева E. K. Биометрия в селекции и генетике сельскохозяйственных животных. - М.: Колос, 1970. - 423 с.

6. Найденко K. А. Вплив показників ембріонального розвитку на ріст і продуктивність корів /
Висновки: 1. Маса телят при народженні до певної міри залежить від їх статі. Бички важчі теличок у середньому на 2,2 кг і мають вищу на 7,34 г (Р>0,999) ембріональну швидкість росту.

2. Не встановлено прямого впливу тривалості ембріогенезу на масу телят при народженні. Тривалість ембріогенезу негативно корелює зі швидкістю росту в ембріональний період ( $\mathrm{r}=-0,27 \ldots-0,33, \mathrm{P}>0,999)$; швидкість росту в ембріональний період зумовлює живу масу телят при народженні (r=0,95, $\mathrm{P}>0,999)$.

3. На масу телят при народженні впливає їх батько ( $\mathrm{h}^{2}=0,10$ при $\left.\mathrm{P}>0,999\right)$, а вплив матері прослідковується лише до четвертого отелення.

4. $70 \%$ усіх отелень, що проходять із допомогою обслуговуючого персоналу, припадає на первісток.

5. Не встановлено суттєвого зв'язку живої маси телят при народженні, швидкості росту телят в ембріональний період та їх статі 3 молочною продуктивністю корів-матерів.

К. А. Найденко, В. І. Вітт, Л. В. Сокальська // Науковий вісник НАУ. - 2002. - Вип. 50. C. 136-139.

7. Некрасов Д. Влияние возраста матерей и продолжительности эмбриогенеза на удой коров / Д. Некрасов // Молочное и мясное скотоводство. - 2008. - №2. - С. 29-30.

8. Сmpixa Л. О. Вплив фактору спадковості на ріст i розвиток бугайців української червоної молочної породи. / Л. О. Стріха // Вісник аграрної науки Причорномор'я. - Вип. 4(43). - 2007. С. 201-208.

9. Хмельничий Л. М. Оцінка екстер'єру тварин в системі селекції великої рогатої худоби : дис. ... доктора с.-г. наук : 06.02.01 „Розведення та селекція тварин" / Л. М. Хмельничий. - Черкаси, 2005. $-430 \mathrm{c}$.

10. Чомаев $A$. Влияние живой массы и возраста телок при первом осеменении на их последующую молочную продуктивность / А. Чомаев, М. Текеев, И. Камбиев // Молочное и мясное скотоводство. - 2010. - №3. - С. 11-13.

11. Щербатий 3. Є. Методи консолідації західного внутріпородного типу української чорнорябої молочної породи при використанні різних генотипових груп чорно-рябої худоби : дис. ... доктора с.-г. наук : 06.02.01,„Розведення та селекція тварин” / 3. Є. Щербатий. - Л., 2002. - 36 с. 